KHAZANAH MULTIDISIPLIN

VOL 1 NO 22020

https://journal.uinsgd.ac.id/index.php/kl

\title{
PERAN PERBANKAN SYARI'AH DALAM PERTUMBUHAN EKONOMI DI INDONESIA
}

\author{
Ahmad Faiz Izzuddin \\ Post Graduate Magister, UIN Sunan Gunung Djati Bandung \\ E-mail: ahmadfaizg573@gmail.com \\ Diterima: 5 Mei 2020, Revisi : 7 Juli 2020 Disetujui : 15 Juli 2020
}

\begin{abstract}
This study aims to examine the growth of Islamic banking which refers to the total data of Islamic banking assets which are currently used as an alternative to measuring the growth of sharia banking, by playing a role in economic development in In donesia. This writing is processed using a literature study method that is obtained from various books, journals, and financial reports, as well as other related references. Data obtained from the annual report at www.ojk.go.id and the central statistical body at www.bps.go.id show that the contribution of Islamic banking is seen from total assets, while the level of Gross Domestic Product (GDP) continues to increase every year. Judging from the Gross Domestic Product (GDP) indicator, it turns out that the growth of Islamic banking in each year is not considered able to encourage economic growth in Indonesia optimally.
\end{abstract}

Keywords: Islamic Banking, GDP, Economic Growth

\begin{abstract}
ABSTRAK
Studi ini bertujuan untuk mengkaji pertumbuhan perbankan syariah yang mengacu pada data total aset perbankan syariah yang saat ini dijadikan salah satu alternatif untuk mengukur pertumbuhan per-bankan syari'ah, dengan berperan pada perkembangan ekonomi di indonesia. Penulisan ini diolah menggunakan medode studi litelatur yang di peroleh dari berbagai macam buku, jurnal, dan laporan keuangan, serta referensi lainnya yang terkait. Adapun data yang diperoleh ilah dari laporan tahunan di www.ojk.go.id dan badan pusat statistik di www.bps.go.id melihatkan bahwa kontribusi perbankan syariah dilihat dari total asset, sementara kadar Prodct Domestik Bruto (PDB) terus bertambah setiap tahunnya. Dilihat dari indikator Produk Domestik Bruto (PDB), ternyata pertumbuhan perbankan syariah di setiap tahunnya dirasa belum mampu mendorong pertumbuhan perekonomian di indonesia dengan optimal.
\end{abstract}

Kata Kunci: Perbankan Syariah, PDB, Pertumbuhan Ekonomi

\section{PENDAHULUAN}

perekonomian yang berbasis Islam salah satunya dalam bidang perbankan khususnya bank Syari'ah. Dilandaskan dengan perinsip syari'ah pada seluruh operasionalnya. Adanya bank syari'ah ini diharapkan dapat meningkatnya pertumbuhan ekonomi di indonesia. Menurut Setiawan (Rama, 2010, hal. 1) perbankan syari'ah yang tuhuan maupun fungsinya dalam gerak perekonomian, yaitu: (1). adil sosial ekonomi, distribusi 


\section{KHAZANAH MULTIDISIPLIN}

VOL 1 NO 22020

https://journal.uinsgd.ac.id/index.php/kl

pendapatan, kekayaan merata, (2). Pelayanan efektif. (3). kesejahteraan ekonomi meluas, tingkat kinerja, pertumbuahn optimal, (4). Stabil mata uang, (5). Memobilisasi, investasi dalam bentuk tabungan.

Adapun beberapa bentuk Perbankan Sayriah di Indonesia, baik Bank Umum Sya'riah atau Bank Pembiayaan Rakyat Syari'ah maupun Unit Usaha Syari'ah. Berlandaskan pada Undang-Undang No. 21 tahun 2008 tentang Perbankan Sya'riah. Terkait aturan Lembaga Keuangan Syari'ah, yang menjadi dukungan peningkatan ekonomi syariah di Indonesia (Penyusun, 2008).

Berkembangnya per-bankan syari'ah di Indonesia hingga kini, ditunjukkan angka yang stable dan increased dari pertumbuhan aset perbankan Syari'ah pada tahun 2011, hingga pada tahun 2017. Sedangkan pertumbuhan ekonomi di Indonesia mengalami kenaikan dan penurunan yang bersifat fluktuatif, dari jangka 5 tahun terakhir, ekonomi di indonesia bertumbuh pada kisaran 5-6\%. Dalam hal ini perlu adanya kajian terdalam dalam pertumbuhan ekonomi di indonesia mengenai peran perbankan syari'ah yang akan di bahas dalam pembahsan. Maka dengan ini, tulisan ini akan mengkaji tentang solusi apa, yang diambil dan meningkatkan kontribusi kemajuan ekonomi di indonesia oleh per-bankan Syari'ah

\section{METODE PENELITIAN}

Studi ini didasari dari metode studi literatur, salah satu metode penelitian dengan mengumpulkan, membaca, serta mencatat studi kepustakaan yang terkait dengan penelitian, lalu mengelolanya sebagai dasar untuk membangun kerangka judul dengan kesatuan yang utuh. (Zed, 2008, hal. 8) Sumber studi literatur ini diperoleh dari berbagai macam buku, jurnal, serta referensi lain yang dapat digunakan dan terkait dengan Peran Per-bankan Syariah dalam Pertumbuhan Ekonomi di Indonesia tercinta.

\section{HASIL DAN PEMBAHASAN}

Perkembangan per-bankan sya'riah di indonesia, dengan mengacu pada Sistem keuangan yang sesuai prinsip syariah. Menjadikan daya tarik 
KHAZANAH MULTIDISIPLIN

VOL 1 NO 22020

https://journal.uinsgd.ac.id/index.php/kl

tersendiri bagi masyarakat majority muslim, dapat mencetuskan pangsa pasar, sangat potential bagi perkembangan perbankan syariah. Pertumbuhan per-bankan sya'riah yang terdaftar di Laporan Tahunan Otoritas Jasa Keuangan (OJK) selama 7 tahun terakhir ini meningkat. Dapat kita di lihat di Tabel 1 Pertumbuhan Per-bankan Syariah Periode 2011-2017 ialah brikut:

Tabel 1. Pertumbuhan Perbankan Syari'ah Periode 2011-2017

\begin{tabular}{|l|c|c|c|c|c|c|c|}
\hline \multicolumn{1}{|c}{ Indikator } & $\mathbf{2 0 1 1}$ & $\mathbf{2 0 1 2}$ & $\mathbf{2 0 1 3}$ & $\mathbf{2 0 1 4}$ & $\mathbf{2 0 1 5}$ & $\mathbf{2 0 1 6}$ & $\mathbf{2 0 1 7}$ \\
\hline Jumlah BUS (Unit) & 11 & 11 & 11 & 12 & 12 & 13 & 13 \\
\hline Jumlah UUS (Unit) & 24 & 24 & 23 & 22 & 22 & 21 & 21 \\
\hline Jumlah Kantor (Unit) & 1.737 & 2.262 & 2.588 & 2.517 & 3.201 & 2.201 & 2.169 \\
\hline Total Asest (triliun) & 145.47 & 195.02 & 242.28 & 272.34 & 296.26 & 356.50 & 424.18 \\
\hline DPK (triliun) & 115.41 & 147.51 & 183.53 & 217.86 & 231.18 & 279.33 & 334.89 \\
\hline Pembiayaan (triliun) & 102.66 & 147.51 & 184.12 & 199.30 & 213.00 & 248.01 & 285.69 \\
\hline NPF (gross) & $2.25 \%$ & $2.22 \%$ & $2.62 \%$ & $4.33 \%$ & $8.20 \%$ & $4.16 \%$ & $3.87 \%$ \\
\hline FDR & $8.94 \%$ & $100.0 \%$ & $100.32 \%$ & $91.50 \%$ & $120.06 \%$ & $88.78 \%$ & $85.31 \%$ \\
\hline
\end{tabular}

Sumber: Laporan Tahunan pada Perbankan Syariah, diakses: www.ojk.go.id

Pertumbuhan per-bankan sya'riah di indonesia sangat pesat. Berdasarkan data tabel diatas, secara kualitas, meningkatnya perbankan sya'riah dibuktikan dengan melonjaknya total bank sya'riah di indonesia. Dimulai di tahun 2011, mencapai 11 Bank Umum Sya'riah, 24 Unit Usaha Sya'riah dan jumlah jaringan kantor mencapai 1,737 unit, Selama 7 tahun Bank Umum Sya'riah mengalami kenaikan. Dalam kurung waktu 2011 sampai 2017, menjadi 13 unit, sedangkan Unit Usaha Sya'riah mengalami keturunan sebesar 21 unit, dengan diikuti menurunnya jumlah jaringan kantor mencapai 2,169 unit, dibandingkan dengan tahun sebelumnya, pada tahun 2013 mencapai 2,588 unit.

Ditabel 1 menunjukan pertumbuhan aset per-bankan Sya'riah naik dari Rp.145,47 triliun di tahun 2011, menjadi Rp.424,18 triliun di tahun 2017. Sementara dana pihak ketiga dan total biaya masing-masing Rp.115,41 triliun dan Rp.102,66 triliun di tahun 2011, mengalami 
KHAZANAH MULTIDISIPLIN

VOL 1 NO 22020

https://journal.uinsgd.ac.id/index.php/kl

peningkatan sebesar Rp.334,89 triliun dan Rp.285,69 triliun pada tahun 2017. Dilihat fari FDR (Financing to Deposit Ratio), dinyatakan rasio pembiayaan disalurkan dengan besarnya dana pihak ketiga (DPK), semua per-bankan Syariah rata-rata FDR mencapai 100\%. Capaian rata-rata FDR mendekati 100\% ini memiliki tingkat kegagalan bayar atau Non Performing Financing (NPF) kurang dari 4\%.

Per-bankan sya'riah ialah salah 1 sumber dalam kemajuan ekonomi maupun di sektor rill. Kinerja dan kerja per-bankan sya'rian, berpengaruh terhadap laju ekonomi dalam suatu negara. Function per-bankan sya'riah yaitu; mengumpulkan dana dari masyarakat dari dana pihak ketiga (DPK). Semakin bertambah dana pihak ketiga pada sektor rill atau produktif maka akan semakin nambah pembangunan fisik modal yang bisa menciptakan pertumbuhan ekonomi menjadi pesat, terkait saat ini, jumlah ke-miskinan dan penggagguran secara langsung akan teratasi melalui kinerja ekonomi yang baik. (Rama, 2010, hal. 2).

Fenomena perkembangan bank syariah di Indonesia, ditabel 1 peningkatan yang signifikan tahun 2011 sampai 2017 semakin ningkat, diukur menggunakan pertumbuhan aset. Kemajuan progress pesat, adanya dukungan regulasi pemerintah. Menututi Alamsyah (Aisy, 2016, hal. 250), keunggulan keuangan syariah dalam bermakna sistem di-Indonesia, tidak dimiliki oleh negara muslim lainnya, yaitu; di berikan kontribusi berkembangnya kelajuan industri per-bankan sya'riah di Indonesia, dan memiliki factor lain yang kontributif diantaranya, ekspansi pengembangan peluasan jaringan kantor bank sya'riah, serta gencarnya besar-besaran outline education dan socialization yang kerjakan oleh Bank Indonesia.

Research yang dikerjakan oleh Syafrida dan Ahmad (Abror, 2011, hal. 7), adanya influence (impact) signifikan rasio FDR terhadapkemajuan progres aset per-bankan sya'riah di-Indonesia. Dengan ini, enhancement FDR akan mengurangi likuidity pada bank sya'riah, sehingga jumlah aset lancar bank menjadi menyusut menurun begitupun aset secara total juga berkurang. 
Per-bankan sya'riah sangat imbas oleh kemajuan kapabilitas dalam menghimpun pengumpul dana masyarakat, baik skala kecil ataupun besar, dari masa deposition yang memadai (Muhammad, Manajemen Dana Bank Syari'ah. Edisi Pertama, 2004, hal. 49).

Element komponen penting yang harus diperhatikan bank dalam rangka memajukan menambah pertumbuhan bank. Hingga dapat counclude menyimpulkan bahwa penambahan maupun pemerosotan volume dana pihak ketiga yang mampu memobilisasi oleh bank syariah secara langsung impresi volume aset bank syari'ah beserta pertumbuhannya. Ibarat partikel dana atau aset bank syari'ah ialah dana titipan dari dana pihak ketiga.

Meningkatkan tatanan ekonomi di suatu negara didampak oleh beberapa indikator parameter. Salah satunya dengan diukurnya Product Domestik Bruto (PDB), baik dari segi harga yang valid maupun atas dasar harga konstan. Dimana nilai angkajumlah barang atau jasa di berbagai unit produksi pembuatan di suatu negara, dalam ukuran batas periode 1 tahun. untuk mengetahui porgres ekonomi dari tahun ke tahun menggunakan data PDB harga konstan, gambar 1:

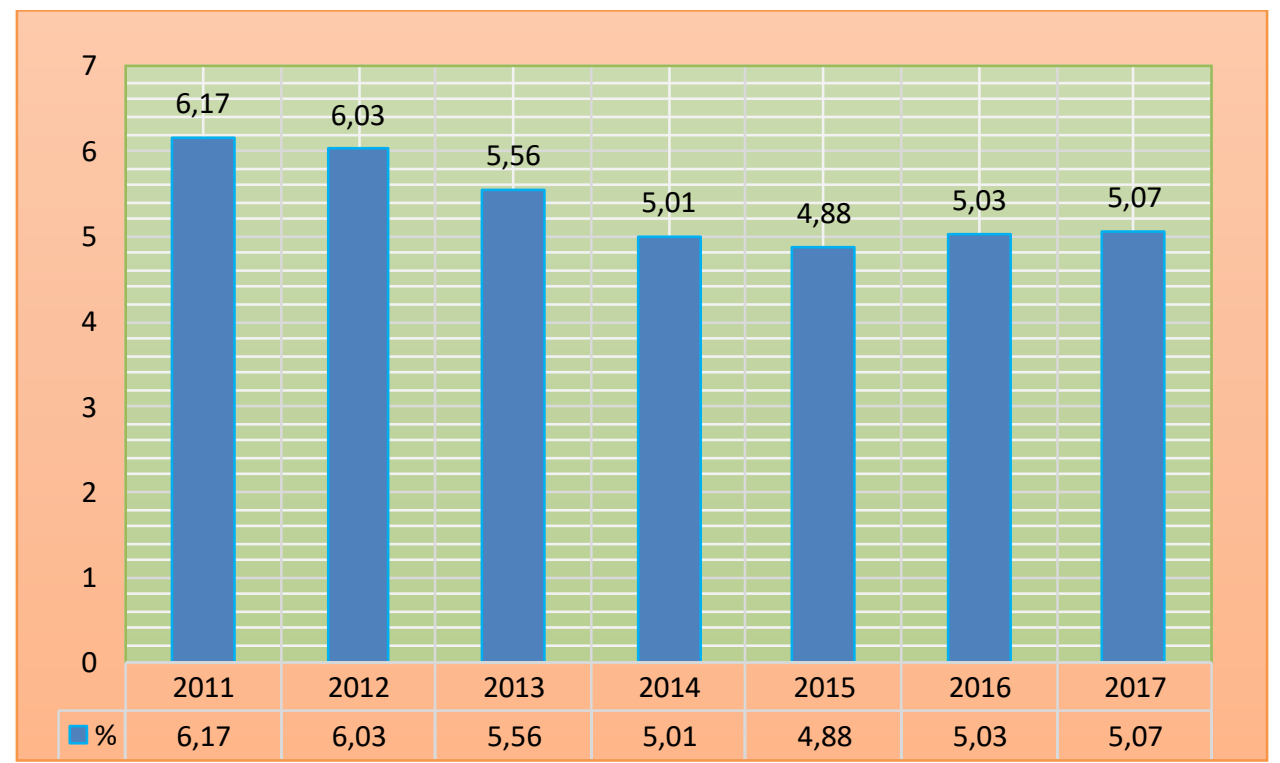

Gambar 1. Pertumbuhan Ekonomi di Indonesia Periode 2011-2017 ( Sumber: Badan Pusat Statistik diakses: www.bps.go.id) 
KHAZANAH MULTIDISIPLIN

VOL 1 NO 22020

https://journal.uinsgd.ac.id/index.php/kl

Gambar 1 menjelaskan bahwa perkembangan ekonomi di indonesia pada tiap tahunnya mengalami kemajuan dan kemunduran yang bersifat fluktuatif. Pada tahun 2015 mengalami penurunan sampai 4,88\%, dan tahun selanjutnya mengalami kenaikan, dari jangka 5 tahun belakang, pertumbuhan progres ekonomi di indonesia berada di putaran 5-6\%. Terjani peningkatan pada tahun 2016 sampai tahun 2017, namun tidak terlalu signifikan terhadap peningkatannya.

Peran bank syari'ah dalam kemajuan ekonomi ialah pe-rbankan sya'riah dalam oprasionalnya lebih menekankan mengendalikan pada tingkat produktifitas sesuai pembiayaan diantaranya; mudharabah serta musyarakah. pembayaran yang diberikan suatu pihak kepada pihak lain untuk berkontribitif dalam invesment, telah dirancang, baik dilakukan sendiri maupun lembaga (Muhammad, 2005, hal. 17). Melintasi model pembiayaan sektor riil dan pe-rbankan syariah akan bergerak maju secara berimbang. Sehingga bank syari'ah akan semakin besar memberi partisipasi sumbangan dana terhadap kerja aktivitas dan kemajuan ekonomi.

\section{SIMPULAN}

Meningkatkan kemajuan ekonomi di suatu negegara dapat berdampak pada beberapa indikator. Salah satunya dengan Produk Domestik Bruto (PDB), baik dasar harga yang berlaku maupun dasar harga konstan. kemajuan ekonomi di indonesia pada tiap tahunnya mengalami kemajuan dan kemunduran yang bersifat fluktuatif. Pada tahun 2015 mengalami penurunan sampai 4,88\%, dan tahun selanjutnya mengalami kenaikan, dari jangka 5 tahun terakhir, pertumbuhan ekonomi di indonesia berada pada kenaikan kisaran 5-6\%. Terjani peningkatan pada tahun 2016 sampai tahun 2017, namun tidak terlalu signifikan terhadap peningkatannya.

Peran per-bankan bank syariah dalam pertumbuhan ekonomi dalam oprasionalnya lebih memfokuskan pada pengembangan produktifitas di 
KHAZANAH MULTIDISIPLIN

VOL 1 NO 22020

https://journal.uinsgd.ac.id/index.php/kl

antaranya pembiayaan mudharabah maupun musyarakah. Memakai paragdigma pola pembiayaan sektor riil dan per-bankan syariah akan bergerak maju dengan cara seimbang. Sehingga menaikan angka perbankan syariah, akan semakin besar kontribusi penyumbang dana di bank syariah terhadapkinerja dan pertumbuhan ekonomi.

\section{DAFTAR PUSTAKA}

Abror, I. S. (2011). Faktor-Faktor Internal Dan Eksternal Yang Mempengaruhi Pertumbuhan Aset Perbankan Syariah Di Indonesia. Jurnal Ekonomi Dan Bisnis, Vol 10, No 1 (Online), (http://jurnalpnj.com/index.php/ekbis/art icle/view/468/pdf_28, diakses pada 11 April 2019). Retrieved from Jurnal Ekonomi Dan Bisnis, Vol 10, No 1 .

Aisy, D. R. (2016). Faktor-Faktor Yang Mempengaruhi Pertumbuhanaset Banksyariahdi Indonesia Tahun 2006-2015. Jurnal Ekonomi Syariah Teori dan Terapan, Vol. 3, No. 3.

Al-Arif, M. N. (2011). Dasar-Dasar Ekonomi Islam. Solo: Era Adicitra Intermedia.

Amalia, E. (2009). Keadilan Distributifdalam Ekonomi Isl am: Penguatan Peran LKM dan UKM di Indonesia . Jakarta: Raja Grafindo Persada.

Antonio, M. S. (2001). Bank Syariah Dari Teori ke Praktik . Jakarta: Gema Insani Press.

Ascarya. (2007). Akad dan Produk Bank Syariah. Jakarta: Raja Grafindo Persada.

Ayub, M. (2009). Understanding Islamic Finance : A - ZKeuangan Syariah , terj. Wisnu Pribadi. Jakarta: Gramedia Pustaka Utama.

Hayati, S. R. (2012, Mei). "Menciptakan dan Mengoptimalkan Sumber Daya Insani" Forum Riset Perbankan Syariah (FRPS) ke - IV Bank Indonesia dan IAEI. Bandung: UNPAD.

Ismail, V. R. (2013). Islamic Risk Management for Islamic Banking: Risiko Bukan untuk Ditakuti, tapi Dihadapi dengan Cerdik, Cerdas, dan Professional . Jakarta: Gramedia Pustaka Utama.

Jusmaliani. (2011). Pengelolaan Sumber Daya Insani . Jakarta: Bumi Aksara.

Muhammad. (2004). Manajemen Dana Bank Syari'ah. Edisi Pertama. Yogyakarta: Ekonisia.

Muhammad. (2005). Manajemen Pembiayaan Bnak Syariah. Yogyakarta: Unit Penerbit dan Percetakan Akademik Manajemen Perpustakaan YKPN. 
KHAZANAH MULTIDISIPLIN

VOL 1 NO 22020

https://journal.uinsgd.ac.id/index.php/kl

Penyusun, T. (2008). Kompilasi Perundang - Undangan tentang Ekonomi Syariah. Jakarta: Gaung Persada Press.

Perwataatmadja, M. S. (1997). Apa dan Bagaimana Bank Islam. Yogyakarta: PT. Dana Bhakti Wakaf.

Rama, A. (2010). Analisis Kontribusi Perbankan Syariah Terhadap Pertumbuahan Ekonomi Indonesia. Jurnal Internasional Islamic University Malaysia, Vol. 2 No. 1.

Silva, E. D. (2013). Analisis Pertumbuhan Ekonomi, Investasi dan Inflasi di Indonesia.Jurnal Ekonomi, Vol 6, No 2.

Siswanto. (2013, Juli Senin). Pengembangan Kualitas SDM Perbankan Syariah Integratif Melalui Implementasi. Workplace Spirituality, " Artikel pada The 2 nd Islamic Economics and Finance Research Forum, p. 2.

Syukry, A. (2013). Pengaruh Pendapatan Asli Daerah dan Dana Alokasi Umum terhadap Belanja Modal serta Dampaknya terhadap Pertumbuhan Ekonomi Daerah. Jurnal Ekonomi, Vol 2, No 2.

Tanjung, K. A. (2007). Bank Syariah: Teori, Praktik, dan Peranannya. Jakarta: Celestial Publishing.

Todaro, M. P. (2002). Pembangunan Ekonomi di Dunia Ketiga. Jakarta: Erlangga.

Usman, V. R. (2012). Islamic Economics and Finan ce: Ekonomi dan Keuangan Islam Bukan Alternatif, tetapi Solusi. Jakarta: Gramedia Pustaka Utama.

Utama, R. L. (2008, Juli). Dicari Bankir Syariah yang Komunikatif, Sharing. Majalah Ekonomi dan Syariah, p. Edisi 19 hlm 10.

Wibowo, E. (2005). Mengapa Memilih Bank Syariah. Bogor: Ghalia Indonesia.

Yusdani. (2005). Perbankan Syariah Berbasis Floating Market. Jurnal Millah IV, Vol. 2, No. 2.

Zed, M. (2008). Metode Penelitian Kepustakaan. Jakarta: Yayasan Obor Indonesia.

\section{INTERNET}

www.ojk.go.id

www.bps.go.id 